\title{
Differential interactions between Curtobacterium flaccumfaciens pv. flaccumfaciens and common bean
}

\author{
S.C.D. Valdo ${ }^{1,2}$, A. Wendland ${ }^{2}$, L.G. Araújo ${ }^{1}$, L.C. Melo ${ }^{2}$, H.S. Pereira ${ }^{2}$, \\ P.G. Melo ${ }^{3}$ and L.C. Faria ${ }^{2}$ \\ ${ }^{1}$ Laboratório de Genética de Microrganismos, Departamento de Genética, \\ Universidade Federal de Goiás, Goiânia, GO, Brasil \\ ${ }^{2}$ Embrapa Arroz e Feijão, Santo Antônio de Goiás, GO, Brasil \\ ${ }^{3}$ Departamento de Genética e Melhoramento de Plantas, \\ Universidade Federal de Goiás, Goiânia, GO, Brasil \\ Corresponding author: A. Wendland \\ E-mail: adriane.wendland@embrapa.br
}

Genet. Mol. Res. 15 (4): gmr15048712

Received April 18, 2016

Accepted June 13, 2016

Published November 21, 2016

DOI http://dx.doi.org/10.4238/gmr15048712

Copyright (C) 2016 The Authors. This is an open-access article distributed under the terms of the Creative Commons Attribution ShareAlike (CC BY-SA) 4.0 License.

\begin{abstract}
Bacterial wilt of common bean caused by Curtobacterium flaccumfaciens pv. flaccumfaciens is an important disease in terms of economic importance. It reduces grain yield by colonizing xylem vessels, subsequently impeding the translocation of water and nutrients to the superior plant parts. The existence of physiological races in $C$. flaccumfaciens pv. flaccumfaciens has not so far been reported. The objective of the present investigation was to identify physiological races, evaluate differential interaction, and select resistant genotypes of common bean. Initially, 30 genotypes of common bean were inoculated with eight isolates exhibiting different levels of aggressiveness, under controlled greenhouse conditions. Disease was assessed 15 days after
\end{abstract}


inoculation. The existence of differential interactions between $C$. flaccumfaciens pv. flaccumfaciens isolates and common bean genotypes were identified by utilizing partial diallel analysis. The most aggressive isolates were BRM 14939 and BRM 14942 and the least aggressive isolates were BRM 14941 and BRM 14946. The genotypes IPA 9, Ouro Branco, and Michelite were selected as more resistant among the test isolates. The genotypes IAC Carioca Akytã, BRS Notável, Pérola, IAC Carioca Aruã, and Coquinho contributed more to the isolate $\mathrm{x}$ genotype interaction according to the ecovalence method of estimation, and were, therefore, indicated as differentials. Based on these results, it was possible to conclude that physiological races of the pathogen exist, to select resistant genotypes, and to propose a set of differentials.

Key words: Genetic resistance; Aggressiveness; Differentiating series; Physiological races; Partial diallels

\section{INTRODUCTION}

Bacterial wilt due to Curtobacterium flaccumfaciens pv. flaccumfaciens (Cff) (Collins and Jones, 1983) results in wilt and death in bean plants (Hedges, 1926). Colonization of the xylem vessels by bacterial cells hinders the passage of water and nutrients to the shoots (Saettler, 1991). In 1995, this disease was reported in the State of São Paulo, Brazil, during the raining season (Maringoni and Rosa, 1997). Bacterial wilt can also be found in several additional Brazilian states, such as Santa Catarina, Goiás, and the Federal District (Uesugi et al., 2003; Theodoro et al., 2007).

The spread and transmission of bacterial wilt occurs via contaminated seeds from sick plants obtained from production fields, wounds and natural openings in plants, and crop residues (Schuster and Sayre, 1967; Saettler, 1991). Thus, the use of healthy seeds, crop rotation, and resistant common bean (Phaseolus vulgaris L.) genotypes are the most commonly recommended methods for controlling bacterial wilt (Hall, 1991). Of these methods, genetic resistance is the most efficient and cheapest way to control this disease in common bean (Wendland et al., 2012). There is no information in the literature on specific interactions in this pathosystem, indicating the existence of physiological races of the pathogen and host-specific resistance. For this reason, the present investigation is original and so far has not been reported elsewhere.

To obtain resistant cultivars, a genetic improvement program must consider pathogenic variability, genetic control over pathogen resistance, and methods of evaluating resistant genotypes. An adaptation of the partial diallel analysis method proposed by Melo and Santos (1999), which uses Griffing's model IV (Griffing, 1956), has been used to evaluate the reaction of a host genotype to inoculation with various pathogen isolates. This method permits the evaluation of a specific interaction between pathogen virulence genes and host resistance genes in a polygenic pathogen-host interaction system and the classification of physiological specialization into isolates of C. flaccumfaciens pv. flaccumfaciens (vertical resistance/ virulence). The method also allows for the selection of superior genotypes based on the host's overall reaction (horizontal resistance) to inoculation, with isolates having different levels of aggressiveness and with genotype-specific reactions (vertical resistance/specific resistance) to inoculation with isolates of specific levels of pathogenicity or virulence.

Genetics and Molecular Research 15 (4): gmr15048712 
Physiological specialization in the species C. flaccumfaciens pv. flaccumfaciens has not been reported. Identifying races that affect common bean genotypes in Brazil is important for the development of genetic improvement programs, as the genetic resistance of cultivars can be overcome. Methods exist for stable bean production, which were developed for genotypeenvironment interaction studies within genetic improvement programs. Some analytical methods are commonly utilized in breeding programs for grain-yield stability, and tests are conducted under different environmental conditions to delineate genotype performance.

However, such methods can be adapted for use in pathogen-host interaction studies. Among these methods are the ecovalence estimate by Wricke (1965) and the method by Lin and Binns (1988), which was modified by Carneiro (1998). The ecovalence estimate described by Wricke (1965) can also be used to measure the contribution of each genotype in the genotype $\mathrm{x}$ isolate interaction; the sum of squares of the interaction is broken down into fractions related to the genotypes, and isolates that are more unstable can be identified. The method by Lin and Binns (1988) is used to recommend cultivars for favorable and unfavorable environments. This method can also be used to recommend genotypes for conditions in which pathogens with high or low aggressiveness occur; stability among resistant genotypes can also be described. Therefore, this method can be used to break down the genotype reaction within more and less aggressive groups of isolates.

The objective of identifying physiological specializations is to develop germplasm with genes effective against these pathogens. To achieve this, it is necessary to obtain a series of different physiological races of C. Alaccumfaciens pv. flaccumfaciens. Once these have been obtained, it is possible to incorporate resistance genes into commercial cultivars and to develop resistant cultivars. Therefore, it is necessary to evaluate the horizontal and vertical resistance capacity of common bean genotypes against different $C$. flaccumfaciens pv. flaccumfaciens isolates and to understand their variability (aggressiveness and virulence).

The aim of the present study was to evaluate the horizontal and vertical resistance of common bean genotypes against different $C$. flaccumfaciens pv. flaccumfaciens isolates and to determine their variability (aggressiveness and virulence). The existence of pathogen $\mathrm{x}$ host interactions and, consequently, the existence of physiological races in the common bean, $C$. flaccumfaciens pv. flaccumfaciens pathosystem, was tested.

\section{MATERIAL AND METHODS}

\section{Origin of isolates and genotype performance}

The C. flaccumfaciens pv. flaccumfaciens isolates used in these experiments were selected based on their aggressiveness determined by inoculating Ouro Branco, BRS Esplendor and CNFP 10132 genotypes. Inoculations of these three genotypes included 24 isolates obtained from plant samples of common bean (Phaseolus vulgaris) collected from different parts of Brazil (Table 1). The plants were inoculated 11 days after planting under controlled greenhouse conditions. The lay-out was a completely randomized block design with three repetitions. A control inoculated with water was maintained. Disease was assessed 14 and 21 days after inoculation, utilizing a visual rating scale of 1 to 9 based on disease severity, where 1 corresponds to the absence of symptoms and 9 corresponds to dead plants (Wendland et al., 2009). The data were submitted to analysis of variance and the means were separated by the Scott-Knott test (Scott and Knott, 1974) using the statistical program Sisvar (Ferreira, 1999).

Genetics and Molecular Research 15 (4): gmr15048712 
Table 1. Origin of the Curtobacterium flaccumfaciens pv. flaccumfaciens isolates originated from common bean, belonging to the collection of fungus and microorganism multifunctional of Embrapa Rice and Beans.

\begin{tabular}{|c|c|c|}
\hline Isolates & Genotypes & Origin \\
\hline BRM 14910 & CNFC10758 & Ponta Grossa, PR \\
\hline BRM 14910 & CNFC10758 & Ponta Grossa, PR \\
\hline BRM 14912 & CNFC10758 & Ponta Grossa, PR \\
\hline BRM 27254 & Pérola & Luziânia, GO \\
\hline BRM 14913 & CNFC11970 & Ponta Grossa, PR \\
\hline BRM 14914 & Light Red Kidney & Anápolis, GO \\
\hline BRM 14915 & Dark Red Kidney & Anápolis, GO \\
\hline BRM 14919 & Pérola & Anápolis, GO \\
\hline BRM 14922 & Grão Carioca & Ponta Grossa, PR \\
\hline BRM 14933 & Rubi & Wenceslau Bras, PR \\
\hline BRM 14934 & Bola Cheia & Wenceslau Bras, PR \\
\hline BRM 14935 & Pérola & Angatuba, SP \\
\hline BRM 14936 & - & Taquarituba, SP \\
\hline BRM 14937 & Iapar & Itararé, PR \\
\hline BRM 14938 & Cometa & Angatuba, SP \\
\hline BRM 14939 & Pérola & Paranapanema, SP \\
\hline BRM 27216 & Rubi & Tibaji, PR \\
\hline BRM 14942 & - & Campos Novos, SC \\
\hline BRM 14940 & - & Wenceslau Braz, PR \\
\hline BRM 14941 & - & Pato Branco, PR \\
\hline BRM 14945 & - & Wenceslau Braz, PR \\
\hline BRM 14944 & - & Wenceslau Braz, PR \\
\hline BRM 14943 & - & Wenceslau Braz, PR \\
\hline BRM 14946 & - & Brasília, DF \\
\hline
\end{tabular}

\section{Pathogenicity tests}

Genotypes of Andian and Mesoamerican origin, which are used in a breeding program of Embrapa rice and bean, were selected. According to Miklas et al. (2006), in order to obtain durable resistance, it is necessary to obtain cultivars possessing resistance genes derived from both gene pools, because the pathogen is capable of infecting genotypes of both origins.

The following genotypes were used: Coquinho, BRS Cometa, BRS Estilo, Vermelho, BRS Esplendor, BRS Esteio, BRS Notável, IAC Carioca Pyatã, IAC Carioca Akytã, IAC Carioca Aruã, Pérola, BRS Requinte, Uirapuru, BRS Campeiro, A 211, IPA 6, Frijólica 0-3-1, BAT 477, IPA 1, TU, TO, AND 277, Widusa, Michelite, IPA 7419, Cornell 49242, PI 207 262, IPA 9, Ouro Branco, and CNFRS 11997.

Two trials were conducted in a greenhouse in 2011 and 2012. A random-block design was used with three replicates and an uninoculated control. A split-plot scheme was utilized, where the plots and subplots comprised isolates and genotypes, respectively. The genotypes were sowed in $1.5 \mathrm{~kg}$ pots containing $1 / 2$ soil and $1 / 2$ Bioflora substrate. The isolates were cultured on Petri dishes containing nutrient agar culture medium and incubated in a growth chamber at $28^{\circ} \mathrm{C}$ for $48 \mathrm{~h}$. Bacterial suspensions of each isolate were diluted and adjusted to concentrations of $10^{8} \mathrm{CFU} / \mathrm{mL}$. Inoculations were performed 10 days after planting with two perforations in the epicotyl. A 1-mL syringe was used to apply $100 \mu \mathrm{L}$ inoculum to each hole. In the control, $10 \mu \mathrm{L}$ sterile distilled water was injected into each hole. Both experiments were evaluated 15 days after inoculation. A disease severity score scale ranging from 1 to 9 , as proposed by Wendland et al. (2009), was used as follows: 1, no symptoms; 2, mosaic in the leaves; 3 , leaf flaccidity; 4, flaccidity and mosaic in the leaves; 5 , flaccidity or mosaic in 
the leaves combined with burned or wizen leaf board; 6, plant dwarfism; 7, plant dwarfism combined with additional symptoms other than plant wilting or only symptoms of plant wilting; 8, plant wilting combined with other symptoms; and 9, plant death.

\section{Data analysis}

Data concerning bacterial wilting were subjected to individual and joint analyses of variance. The mean of each treatment, the general reaction ability (GRA), general aggressivity ability (GAA), and specific interaction ability (SIA) were estimated following the method proposed by Melo and Santos (1999). For this procedure, an adaptation of Griffing's model IV (Griffing, 1956) in a partial diallel scheme was used as described by Geraldi and Miranda-Filho (1988). Group I comprised 30 host genotypes, and group II comprised eight pathogen isolates. In pathogen-host interactions, GRA represents the horizontal resistance of genotypes to different pathogen isolates (physiological races). The GAA of the pathogen represents the aggressiveness of each physiological race when inoculating all host genotypes. The SIA indicates the interaction between the components of the two groups. This estimate represents the physiological race's virulence and the genotype's vertical resistance. The mathematical model proposed to analyze the polygenic pathogen-host interaction with partial diallels was as follows:

$$
Y_{I J}=\mu+r_{i}+\alpha_{j}+s_{i j}
$$

(Equation 1)

where $Y_{i j}$ is the disease severity exhibited by the ith host when inoculated with the jth isolate; $r_{i}$ is the effect of the horizontal resistance of the ith genotype; $\alpha_{j}$ is the effect of the aggressiveness of the jth isolate; and $s_{i j}$ is the effect of the interaction between the ith host and the jth isolate relative to the effect of the virulence of the jth isolate with the vertical resistance of the ith genotype.

Analyses of genotype $\mathrm{x}$ isolate interactions were performed within the joint analysis of the two trials. The GENES software (Cruz, 2013) was used to estimate stability using the ecovalence method of Wricke (1965); this method measures the contribution of each genotype to the genotype $\mathrm{x}$ isolate interaction. Next, the stability of the genotype was estimated using the method described by Lin and Binns (1988). Isolates were stratified into more aggressive and less aggressive groups. Pearson correlation analysis was performed, first with four genotypes, later with 26, and finally with 30 genotypes to evaluate specific reactions to the isolates.

Pairs were considered to differ when the correlation was low and not significant or negative. The isolate pairs with weaker correlations were considered to be more informative and different. Such pairs were considered to have high genotype $\mathrm{x}$ isolate interactions, i.e., gene-for-gene interactions occurred.

Using Wricke's (1965) ecovalence, it was possible to calculate the percentage of the genotype $\mathrm{x}$ isolate $(\mathrm{G} x \mathrm{I})$ interaction due to each genotype $\left(\mathrm{W}_{\mathrm{i}}^{2 \%} \%\right)$. This value is given by the following equation:

$$
W_{i}^{2} \%=\left(v_{i}^{2} / \sum v_{i}\right)^{2} \times 100
$$

More stable genetic material is considered to have a lower ecovalence estimate, i.e., such material makes a smaller contribution to the G x I interaction. The candidate genotypes

Genetics and Molecular Research 15 (4): gmr15048712 
were those that exhibited strong interactions $\left(\mathrm{W}_{\mathrm{i}}^{2}\right)$ with the eight inoculated isolates, which enabled differentiation between races. For this, the sum of squares of the $\mathrm{G} x \mathrm{I}$ interaction was broken down into portions for each genotype according to the following equation:

$$
\mathrm{W}_{\mathrm{i}}^{2}=\sum_{\mathrm{j}=1}^{\mathrm{n}}\left(\mathrm{Y}_{\mathrm{ij}}-\mathrm{Y}_{\mathrm{i} .}-\mathrm{Y}_{\mathrm{j}}+\mathrm{Y}_{. .}\right)^{2} \quad \text { (Equation 3) }
$$

where $Y_{i j}$ is the mean of genotype $\mathrm{i}$ in isolate $\mathrm{j} ; Y_{i .}$ is the mean of genotype $\mathrm{i} ; Y_{. j}$ is the mean of isolate $\mathrm{j}$; and $Y$ is the overall mean.

The method described by Lin and Binns (1988) and modified by Carneiro (1998), was used to estimate the stability of the genotypes in each aggressiveness group of C. Alaccumfaciens pv. flaccumfaciens isolates. This method can be used to identify one or more genotypes with performance farthest from the most susceptible genotype for the isolates tested. Using this method, genotype stability was estimated using the $P_{i}$ stability index. The $P_{i}$ stability index is the estimated mean-square of the distance between the mean of genotype $i$ and the mean of the most susceptible genotype for each isolate (Daher et al., 2003). The genotype that exhibited the highest $P_{i}$ value was the most stable among the resistant genotypes. The following formula was used to obtain this estimate:

$$
P_{i}=\sum_{j=1}^{n} \frac{\left(X_{i j}-M_{j}\right)^{2}}{2 n}
$$

where $P_{i}$ is the estimated stability of genotype $\mathrm{i} ; X_{i j}$ is the reaction of the $\mathrm{i}$-ith genotype in the $\mathrm{j}$-ith isolate; $M_{j}$ is the maximum response observed among all of the genotypes in isolate $\mathrm{j}$; and $n$ is the number of isolates.

With the estimated $P_{i}$ stratified between more and less aggressive isolates, it was also possible to test the individual behavior of genotypes when inoculated with these two groups of isolates. Isolates caused disease above the mean $\left(P_{i}^{+}\right)$or below the mean $\left(P_{i}\right)$ of all the isolates.

\section{RESULTS}

\section{Evaluation of genotypes for resistance and aggressiveness/virulence of isolates}

Evaluation of genotypes for the resistance and aggressiveness/virulence of isolates was performed by utilizing 24 isolates of $C$. flaccumfaciens pv. flaccumfaciens. The isolates were classified into four aggressiveness groups according to the Scott-Knott test. Of the 24 strains, BRM 27254, BRM 14919, BRM 14933, BRM 14935, BRM 14939, BRM 14946, BRM 14942, and BRM 14941 were selected; this selection includes two strains from each group and covers six different Brazilian regions.

In the individual analyses performed during both sowing trials, there were significant differences among genotypes, among isolates, and among the isolate $\mathrm{x}$ genotype interactions. In the joint analysis, significant differences among isolates were also detected; these findings indicated that the isolates possessed different levels of aggressiveness. The behavior of genotypes differed significantly following inoculation with the eight C. flaccumfaciens pv. flaccumfaciens isolates. The effects of the isolate $\mathrm{x}$ genotype, isolate $\mathrm{x}$ trial, and genotype $\mathrm{x}$ trial interactions were also significant. Significant differences were observed in the interaction

Genetics and Molecular Research 15 (4): gmr15048712 
genotype $\mathrm{x}$ isolate $\mathrm{x}$ trial, indicating that the genotypes exhibit differences when inoculated with different isolates and when evaluated at distinct times. There were no significant differences between the replicates of each trial, indicating homogeneity in the environmental conditions of the greenhouse (Table 2).

Table 2. Variance analyses of bacterial wilt severity in 30 common bean genotypes in response to eight isolates of Curtobacterium flaccumfaciens pv. flaccumfaciens.

\begin{tabular}{|c|c|c|c|c|}
\hline Source of variation & d.f. & MS & $F$ test & $\mathrm{P}$ value \\
\hline Trials & 1 & 4.33 & 7.8 & 0.00 \\
\hline Isolate & 7 & 38.63 & 69.58 & 0.00 \\
\hline Isolate $\mathrm{x}$ trial & 7 & 14.33 & 25.82 & 0.00 \\
\hline Replication (trial) & 4 & 0.75 & 1.35 & 0.27 \\
\hline Error1 & 28 & 0.55 & - & - \\
\hline Genotype & 29 & 11.73 & 17.73 & 0.00 \\
\hline Genotypes $\mathrm{x}$ trials & 29 & 6.16 & 9.31 & 0.00 \\
\hline Genotypes $\mathrm{x}$ isolate & 203 & 4.38 & 6.62 & 0.00 \\
\hline Genotypes $\mathrm{x}$ isolate $\mathrm{x}$ trials & 203 & 2.47 & 3.74 & 0.00 \\
\hline Error2 & 928 & 0.66 & - & - \\
\hline Coefficient of variation $1(\%)$ & 25.25 & & & \\
\hline Coefficient of variation $2(\%)$ & 27.57 & & & \\
\hline General mean & 2.95 & & & \\
\hline
\end{tabular}

d.f.: degrees of freedom; MS: mean square; $\mathrm{P}$ value indicates the probability that means are not significantly different ( $F$ test)

In the diallelic analysis used to investigate the interaction between different genotypes and isolates, all sources of variation were significant $(\mathrm{P}<0.05)$ in both individual and joint analyses (Table 3). The effects of GRA and GAA remained significant throughout different trials. As there was a significant interaction between isolates and genotypes in the different trials, it can be inferred that common bean genotypes and C. flaccumfaciens pv. flaccumfaciens isolates exhibited different responses when evaluated during different trials. These findings confirm the need to perform several experiments to obtain more precise estimates, even when inoculation is performed under controlled conditions. There were significant differences in the estimated horizontal resistance (GRA) of the genotypes studied, suggesting that some genotypes have a higher mean degree of resistance to the isolates tested. In the analysis of the estimated horizontal resistance of the genotypes inoculated with eight $C$. flaccumfaciens pv. flaccumfaciens isolates, 11 GRA estimates were significant. The isolates exhibited significantly different GAA both in individual experiments and in the joint analysis (Table 3 ). These data indicate that the isolates differ in their mean degree of disease severity. The SIA, which evaluates pathogen virulence/host vertical resistance, also differed significantly. This indicates the existence of specific resistance in some genotypes.

The SIA $x$ trial interaction was significant $(\mathrm{P}<0.05)$, indicating that the genotype $\mathrm{x}$ isolate interactions responded differently depending on the trial in which the experiment took place. These results show that the physiological specialization behaved differently during different trials (Table 3). The IPA 9, Ouro Branco, Michelite, BRS Requinte, and TU genotypes exhibited the most significant negative estimates (horizontal resistance). In contrast, the TO, Cornell 49242, IAC Carioca Pyatã, Uirapuru, IPA 7419, PI 207 262, Widusa, IPA 6, Pérola, BAT 477, BRS Esplendor, CNFC 10408, BRS Estilo, Vermelho, BRS Campeiro, IAC Carioca Aruã, AND 277, IAC Carioca Akytã, and IPA 1 genotypes did not exhibit significant GRA estimates. Therefore, these genotypes do not undergo horizontal resistance to the inoculated 
isolates. The BRS Cometa, A 211, Coquinho, CNFP 10104, CNFRS 11997, and Frijólica 0-31 genotypes exhibited significant positive GRA estimates, indicating that these genotypes are highly susceptible to bacterial wilt (Table 4).

Table 3. Analysis of joint diallelic variance of the severity of Curtobacterium wilt using 30 common bean genotypes and eight Curtobacterium flaccumfaciens pv. flaccumfaciens isolates.

\begin{tabular}{|c|c|c|c|c|}
\hline Source of variation & d.f. & MS & $F$ test & $\mathrm{P}$ value \\
\hline Treatments iIsolates $\mathrm{x}$ genotypes) & 239 & 6.40 & 9.71 & 0.00 \\
\hline GRA (horizontal resistance) & 29 & 11.78 & 17.85 & 0.00 \\
\hline GAA (aggressivity) & 7 & 36.09 & 54.69 & 0.00 \\
\hline SIA (interaction) & 203 & 4.61 & 6.99 & 0.00 \\
\hline Environments & 1 & 6.87 & 10.41 & 0.00 \\
\hline Treatments $\mathrm{x}$ environments & 239 & 3.12 & 4.73 & 0.00 \\
\hline GRA $x$ environments & 29 & 5.63 & 8.53 & 0.00 \\
\hline GAA $\mathrm{x}$ environments & 7 & 12.37 & 18.75 & 0.00 \\
\hline SIA $\mathrm{x}$ environments & 203 & 2.44 & 3.70 & 0.00 \\
\hline Error & 478 & 0.66 & - & - \\
\hline Mean: 2.95 & & & & \\
\hline
\end{tabular}

d.f.: degrees of freedom; MS: mean square; $\mathrm{P}$ value indicates the probability that means are not significantly different ( $F$ test). GRA: general reaction ability; GAA: general ability of aggressivity; SIA: specific interaction ability.

A total of 240 combinations of virulence/vertical resistance interactions between the isolates and genotypes were generated. Of these, 65 combinations were significant, which represent specific interactions between pathogen physiological races and common bean genotypes (Table 4). This estimate includes negative and positive values, which indicate the presence or absence of resistance to an isolate, respectively. Of the significant estimates, 32 were negative. Negative values indicate the presence of specific resistance in a given genotype. The combinations that exhibited the lowest estimated SIA were AND 277 x BRM 14935; CNFP 10104 x BRM 14919; TU x BRM 14933; CNFC 10408 x BRM 14941; and Coquinho x BRM 14919. These genotypes exhibited greater specific resistance to these isolates.

The IPA 9 genotype exhibited high estimated horizontal resistance to all of the isolates; however, none of the estimated SIA values were significant (Figure 1). Although this genotype did not exhibit specific resistance to any isolate in the set, it exhibited low means in the evaluations by exhibiting horizontal resistance to all of the inoculated isolates (Table 4). The CNFRS 11997 genotype exhibited the lowest horizontal resistance, indicating high susceptibility to bacterial wilt. However, this genotype exhibited significant interactions in the interaction estimates. Specific resistance to the isolates BRM 14939, BRM 14919, and BRM 14946 was observed (Table 4). Therefore, the IPA 9 and CNFRS 11997 genotypes were the most contrasting in terms of their reactions to $C$. flaccumfaciens pv. flaccumfaciens isolates (Figure 1).

The four genotypes with greatest horizontal resistance were analyzed in terms of their specific resistance to the eight isolates. The IPA 9 and BRS Requinte genotypes exhibited the greatest stability regarding reactions, whereas Ouro Branco and Michelite were less stable, exhibiting higher variation for isolate virulence (Figure 1).

Genetics and Molecular Research 15 (4): gmr15048712 
Variability in C. flaccumfaciens pv. flaccumfaciens strains

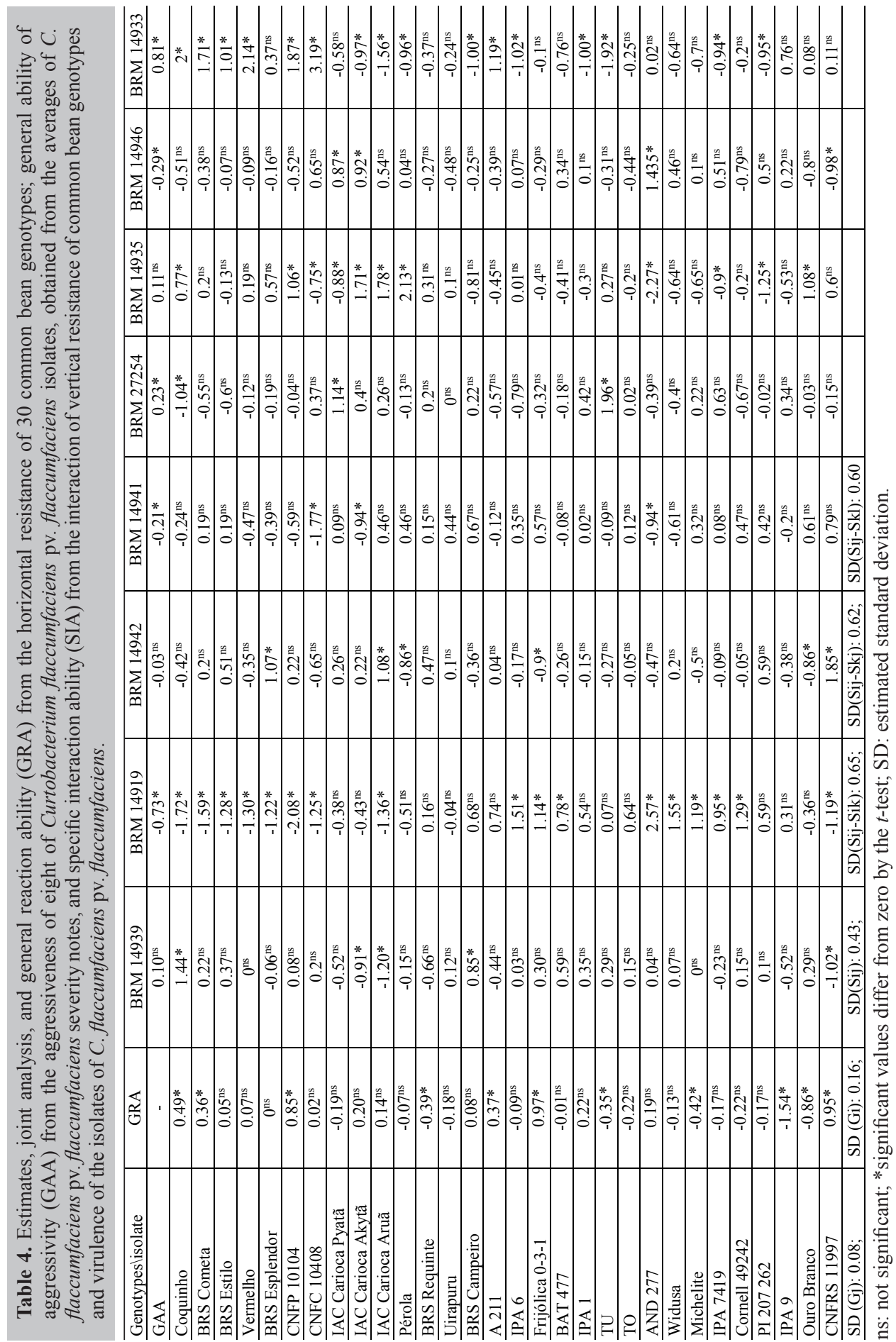

Genetics and Molecular Research 15 (4): gmr15048712 


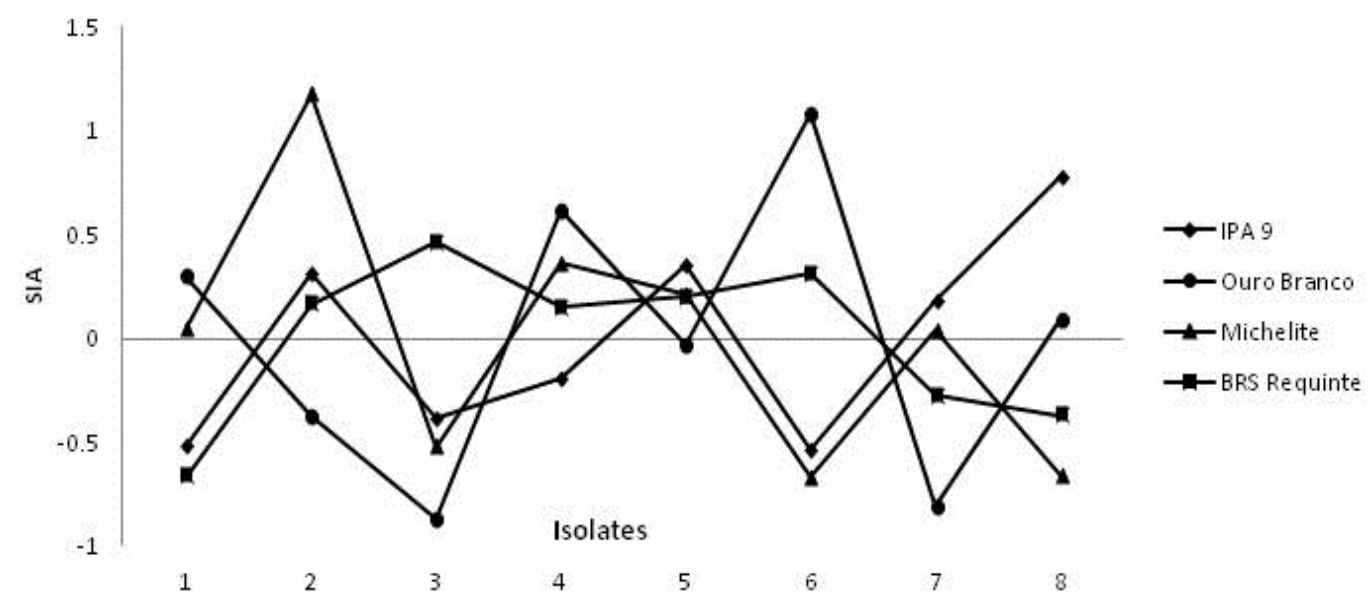

Figure 1. Specific interaction ability (SIA) in the joint analysis of four common bean genotypes that presented the highest estimates of general reaction ability (GRA), inoculated with eight isolates of Curtobacterium flaccumfaciens pv. flaccumfaciens: 1, BRM 14939; 2, BRM 14919; 3, BRM 14942; 4, BRM 14941; 5, BRM 27254; 6, BRM 14935; 7, BRM 14946; 8, BRM 14933.

\section{Analysis of interaction between isolates and genotype stability}

Using the 30 genotypes, the mean estimated correlation between the isolate pairs was 0.21. These data are shown in Table 5. The following four isolate pairs exhibited significant positive intermediate correlations: BRM 14939 and BRM 14933; BRM 14942 and BRM 14941; BRM 14942 and BRM 14935; and BRM 14941 and BRM 14935. These isolates were classified similarly. The BRM 27254, BRM 14919, and BRM 14946 isolates are not correlated with any other isolate. Therefore, these isolates are most likely different, and the fact that they exhibited strong interactions indicates the existence of specific physiological races. The BRM 14919 isolate exhibited four negative correlations, indicating that it differs the most from the other eight isolates. When determining the Pearson correlation between the isolate pairs using only the four most extreme genotypes, i.e., those that exhibited the lowest (IPA 9 and Ouro Branco) and the highest (Frijólica 0-3-1 and CNFRS 11997) severity means, the correlation was high (0.79). This result suggests that these genotypes contain horizontal resistance genes that have a greater effect, and that it is not possible to detect gene-for-gene interactions. When the Pearson correlation was determined using only the 26 genotypes with intermediate reactions, i.e., genotypes with median resistance, the lowest correlation value of the three different genotype sampling simulations was obtained. This indicates that the predominant presence of genes with small and medium effects favors the occurrence of $\mathrm{G} \mathrm{x}$ I interactions and allows for higher stratification of the isolates into different physiological races groups. This stratification can be observed by the more frequent occurrence of negative correlations among the isolates. This permitted the detection of more specific and different reactions among the isolates evaluated. 
Table 5. Estimates, joint analysis, and Pearson correlation of severity of eight Curtobacterium flaccumfaciens pv. flaccumfaciens isolates in 4, 26, and 30 common bean genotypes.

\begin{tabular}{|c|c|c|c|}
\hline \multirow[t]{2}{*}{ Isolate } & \multicolumn{3}{|c|}{ Correlation } \\
\hline & 4 Genotypes & 26 Genotypes & 30 Genotypes \\
\hline BRM $14939 \times$ BRM 14919 & 0.87 & -0.08 & 0.17 \\
\hline BRM 14939 x BRM 14942 & 0.50 & 0.002 & 0.25 \\
\hline BRM $14939 \times$ BRM 14941 & 0.89 & 0.18 & 0.43 \\
\hline BRM $14939 \times$ BRM 27254 & 0.81 & -0.14 & 0.16 \\
\hline BRM $14939 \times$ BRM 14935 & 0.77 & 0.03 & 0.21 \\
\hline BRM $14939 \times$ BRM 14946 & 0.81 & -0.009 & 0.30 \\
\hline BRM 14939 x BRM 14933 & 0.78 & $0.53^{* *}$ & $0.51^{* *}$ \\
\hline BRM $14919 \times$ BRM 14942 & 0.37 & -0.38 & -0.06 \\
\hline BRM 14919 x BRM 14941 & 0.70 & -0.02 & 0.19 \\
\hline BRM $14919 \times$ BRM 27254 & 0.74 & -0.26 & -0.03 \\
\hline BRM $14919 \times$ x BRM 14935 & 0.44 & $-0.62 * *$ & -0.41 \\
\hline BRM $14919 \times$ x BRM 14946 & 0.90 & 0.13 & 0.31 \\
\hline BRM 14919 x BRM 14933 & 0.77 & $-0.46^{*}$ & -0.32 \\
\hline BRM $14942 \times$ BRM 14941 & 0.83 & 0.24 & $0.56^{* *}$ \\
\hline BRM $14942 \times$ BRM 27254 & 0.89 & 0.04 & 0.40 \\
\hline BRM $14942 \times$ BRM 14935 & 0.80 & $0.40^{*}$ & $0.50^{* *}$ \\
\hline BRM $14942 \times$ BRM 14946 & 0.71 & 0.22 & 0.42 \\
\hline BRM $14942 \times$ BRM 14933 & 0.87 & 0.24 & 0.30 \\
\hline BRM 14941 x BRM 27254 & $0.966^{*}$ & -0.18 & 0.23 \\
\hline BRM $14941 \times$ x BRM 14935 & 0.93 & 0.26 & $0.46 * *$ \\
\hline BRM $14941 \times$ x BRM 14946 & 0.84 & -0.33 & 0.07 \\
\hline BRM 14941 x BRM 14933 & 0.92 & -0.22 & 0.01 \\
\hline BRM $27254 \times$ x BRM 14935 & 0.84 & 0.11 & 0.27 \\
\hline BRM 27254 x BRM 14946 & 0.92 & 0.22 & 0.43 \\
\hline BRM 27254 x BRM 14933 & $0.99 * *$ & -0.13 & 0.00 \\
\hline BRM $14935 \times$ x BRM 14946 & 0.60 & -0.02 & 0.10 \\
\hline BRM $14935 \times$ BRM 14933 & 0.76 & 0.18 & 0.24 \\
\hline BRM 14946 x BRM 14933 & $0.95^{*}$ & 0.16 & 0.22 \\
\hline Mean & 0.79 & 0.003054 & 0.21 \\
\hline
\end{tabular}

**Significant at $\mathrm{P}<0.05 .{ }^{*}$ Significant at $\mathrm{P}<0.01$.

The genotypes that exhibited higher ecovalence (Wricke, 1965) estimates were CNFRS 11997 (9.6) and IAC Carioca Akytã (9.2), and the BRS Notável, Pérola, IAC Carioca Aruã, and Coquinho. These genotypes exhibited estimates above 7\% and contributed most to the interaction effect observed among isolates and genotypes. The IPA 1, Vermelho, and BRS Requinte genotypes exhibited lower ecovalence estimates; they interacted the least with the isolates (Table 6).

Table 6 shows the estimated stability values of the 30 genotypes when inoculated with different isolates. These data were obtained according to the method described by Lin and Binns (1988). The isolates were classified as more aggressive $(\mathrm{Pi}[+])$ (with a mean disease severity above the overall mean) or less aggressive (Pi[-]) (with a mean disease severity below the overall mean). The most aggressive isolates were BRM 14939, BRM 14942, BRM 27254, BRM 14935, and BRM 14933. The least aggressive isolates were BRM 14919, BRM 14941, and BRM 14946.

Genetics and Molecular Research 15 (4): gmr15048712 
Table 6. Estimate stability of 30 common bean genotypes evaluated with eight Curtobacterium flaccumfaciens pv. flaccumfaciens isolates, based on the ecovalence (Wi) and the method described by Lin and Binns (1988).

\begin{tabular}{|c|c|c|c|c|c|c|}
\hline \multirow[t]{2}{*}{ Genotypes } & \multirow{2}{*}{ Mean } & \multirow{2}{*}{ Wi (\%) } & \multicolumn{4}{|c|}{ Lin and Binns } \\
\hline & & & $P i(+)$ & $\mathrm{C}^{1}$ & $P i(-)$ & $C$ \\
\hline IPA 9 & 1.34 & 1.42 & 12.90 & 1 & 8.82 & 2 \\
\hline TO & 2.15 & 1.68 & 7.92 & 8 & 9.16 & 1 \\
\hline Ouro Branco & 2.18 & 1.12 & 7.46 & 11 & 7.91 & 5 \\
\hline BRS Requinte & 2.25 & 0.63 & 6.60 & 13 & 7.91 & 4 \\
\hline Michelite & 2.32 & 2.77 & 10.10 & 2 & 3.63 & 22 \\
\hline AND 277 & 2.36 & 3.65 & 8.59 & 5 & 6.83 & 9 \\
\hline Widusa & 2.45 & 2.78 & 8.07 & 7 & 6.88 & 7 \\
\hline PI 207262 & 2.46 & 2.80 & 8.28 & 6 & 4.21 & 20 \\
\hline TU & 2.53 & 3.07 & 8.62 & 4 & 4.64 & 16 \\
\hline IPA 7419 & 2.53 & 3.29 & 9.30 & 3 & 3.54 & 27 \\
\hline Uirapuru & 2.55 & 1.01 & 5.83 & 16 & 6.41 & 11 \\
\hline BRS Esplendor & 2.61 & 1.23 & 4.76 & 21 & 8.01 & 3 \\
\hline Cornell 49242 & 2.65 & 1.08 & 7.17 & 12 & 4.24 & 17 \\
\hline Vermelho & 2.72 & 0.76 & 5.08 & 19 & 6.84 & 8 \\
\hline Pérola & 2.72 & 7.32 & 7.48 & 9 & 5.71 & 13 \\
\hline IPA 6 & 2.78 & 2.14 & 7.46 & 10 & 3.54 & 24 \\
\hline BRS Campeiro & 2.96 & 1.96 & 6.15 & 14 & 3.59 & 23 \\
\hline BAT 477 & 3.08 & 1.10 & 5.86 & 15 & 3.54 & 25 \\
\hline IAC Carioca Pyatã & 3.12 & 3.54 & 5.01 & 20 & 4.77 & 15 \\
\hline BRS Cometa & 3.16 & 1.32 & 3.22 & 27 & 5.84 & 12 \\
\hline IPA 1 & 3.17 & 0.98 & 5.49 & 17 & 3.54 & 26 \\
\hline BRS Notável & 3.21 & 8.67 & 5.31 & 18 & 7.09 & 6 \\
\hline BRS Estilo & 3.27 & 2.73 & 3.42 & 26 & 4.83 & 14 \\
\hline A 211 & 3.41 & 4.39 & 4.50 & 22 & 4.16 & 21 \\
\hline Coquinho & 3.62 & 7.06 & 4.03 & 23 & 4.21 & 18 \\
\hline IAC Carioca Akytã & 3.62 & 9.22 & 3.42 & 25 & 6.66 & 10 \\
\hline Frijólica 0-3-1 & 3.73 & 1.26 & 4.00 & 24 & 1.64 & 29 \\
\hline IAC Carioca Aruã & 3.92 & 7.11 & 2.79 & 28 & 2.90 & 28 \\
\hline BRS Esteio & 4.12 & 4.10 & 1.00 & 29 & 4.21 & 19 \\
\hline CNFRS 11997 & 4.92 & 9.65 & 0.57 & 30 & 1.54 & 30 \\
\hline
\end{tabular}

${ }^{1}$ Genotype rating based on stability in accordance with the Lin and Binns method (1988).

\section{DISCUSSION}

In this study, the partial diallel method proposed by Melo and Santos (1999) was used. It was possible to evaluate the interaction between C. flaccumfaciens pv. flaccumfaciens isolates $\mathrm{x}$ common bean genotypes and characterize the genetic variability existing in this pathosystem. This is the first report describing the use of this method in this pathosystem. Using the environmental stratification methods described by Wricke (1965) and Lin and Binns (1988), it was possible to propose genotypes representing physiological specialization in this pathosystem. To our knowledge, this is the first report to do so in the scientific literature.

Horizontal resistance is non-specific and evenly reduces the development of various pathogen physiological races.

According to Melo and Santos (1999), the horizontal resistance of a genotype is highly correlated with the GRA value. This method has been efficient at evaluating resistance to bacterial wilt in common bean genotypes and the aggressiveness and/or virulence of $C$. flaccumfaciens pv. flaccumfaciens isolates. The IPA 9 and Ouro Branco genotypes exhibited the greatest horizontal resistance to bacterial wilt. The Ouro Branco and CNFRS 11997 genotypes provided contrasting results, indicating the possibility of crossing these two genotypes to obtain lines that are resistant to all eight isolates. Davide and Souza (2009) worked with the Colletotrichum lindemuthianum-bean pathosystem and identified significant differences in the 
virulence of 65 isolates, with the isolates CL 837 and CL 844 being the most virulent. When isolates of the same race exhibit variability, more consistent differentials are needed to detect all pathogen variability. Those authors did not detect horizontal resistance in the pathosystem. The partial diallel method was used to characterize the reaction of the genotypes to these pathogens. Silva (2010) inoculated 50 genotypes with four Xanthomonas axonopodis pv. phaseoli isolates and identified differential interactions between the genotypes and isolates. The aggressiveness of the isolates varied according to the genotype evaluated by partial diallel analysis. This method was also used for cotton; Maranha et al. (2002) found that the BRS Antares and BRS Facual cultivars were the most resistant to Xanthomonas campestris. The BRS Facual cultivar was found to exhibit horizontal resistance. The Ramularia areola cultivar was most resistant, and this resistance was predominantly horizontal. Pereira et. al. (2015) studied variation between Pseudocercospora griseola isolates within the race 63.63. Those authors concluded that there are variability within race 63.63 , wherein isolates differed in the degree of aggressiveness between them. Therefore, in this study, variability was observed within races, representing the first report in this pathosystem.

The method of Melo and Santos (1999) has been informative for several studies using different crops, and has been used to identify differential interactions among genotypes and isolates in these pathosystems. Using this method, it was also possible to conclude that the BRM 14933 isolate had the greatest mean pathogenicity according to the estimated GAA (Table 4). However, 18 genotypes exhibited specific resistance to this isolate (Table 4). The BRM 14919 isolate, despite being less aggressive (Table 4), was highly pathogenic to the IPA6, Frijólica 0-3-1, AND 277, Widusa, Michelite, and Cornell 49242 genotypes. These findings suggest that this isolate is highly virulent to these specific genotypes. The IPA 9 and Ouro Branco genotypes exhibited the greatest horizontal resistance to the isolates tested. The different estimates of horizontal resistance indicate that the genotypes exhibit different allelic compositions for this type of resistance. According to the Pearson correlation results (Table 5), it was necessary to comprehensively sample both the genotypes and isolates to fully represent the pathosystem evaluated. When performing the correlation with only four extreme genotypes, representing the two most resistant and two most susceptible, the results differed from those obtained using 30 genotypes; the mean correlations ranged from 0.21 (using 30 genotypes) to 0.80 (using four extreme genotypes). This finding highlights the importance of good sampling in order to reach consistent conclusions about a pathosystem. A more intense differential interaction is observed when intermediate horizontal resistance genes predominate in the genotypes evaluated. The genotypes that have genes with greater effect have a reduced ability to detect isolate $\mathrm{x}$ genotypes interactions. This occurs because such genotypes exhibit resistance to most physiological races. This feature is similar to genotypes that are highly susceptible, which also have little discriminatory capacity due to a lack of horizontal resistance or specific resistance genes. Genotypes do not interact because of a lack of resistance to any physiological race; therefore, they are unable to discriminate between isolates or races. When performing the correlation with the 26 intermediate genotypes, the correlation was close to zero (0.003). This suggests that the intermediate genotypes contribute more to the interaction than the extreme genotypes, and that genes with intermediate horizontal resistance are more important for detecting this interaction. For differential interaction studies, the selection of genotypes that exhibit intermediate reactions is preferred over genotypes with extreme susceptibility or resistance reactions. Such extreme genotypes do not represent all existing pathogenic variations. To classify C. flaccumfaciens pv. flaccumfaciens isolates by physiological 
specialization, it is necessary to compose a series of differential genotypes that can be used to classify the pathogen isolates by the phenotypic reactions of the genotypes to be inoculated. When estimating the stability of the genotype reactions upon inoculation with different isolates using the method described by Wricke (1965) (Table 6), it was possible to identify the genotypes that contributed most to the genotype-isolate interaction. The CNFRS 11997 genotype made the greatest contribution, as it obtained the largest estimate for this parameter (9.65). This genotype most distinguished the different isolates. Next, the IAC Carioca Akytã genotype contributed $9.22 \%$ of the interaction. This genotype was followed by the genotypes BRS Notável (8.67\%), Pérola (7.32\%), IAC Carioca Aruã (7.11\%), and Coquinho (7.06\%). These genotypes exhibited strong interactions when inoculated with different races, and were the most unstable in the pathosystem studied. According to Wricke's ecovalence (1965), these genotypes are the most efficient at classifying C. flaccumfaciens pv. flaccumfaciens isolates into different races and interact most with the isolates. The genotypes IPA 1, Vermelho, and BRS Requinte obtained the lowest ecovalence estimates, which were all below one. Therefore, the IAC Carioca Akytã, BRS Notável, Pérola, IAC Carioca Aruã, and Coquinho genotypes were used to differentiate $C$. flaccumfaciens pv. flaccumfaciens physiological races. The genotypes that made the greatest contribution to the interaction effects were the isolates with the lowest horizontal resistance estimates. Genotypes with the smallest contributions to this interaction are resistant to bacterial wilt. It is likely that susceptible genotypes do not carry genes of great effect for resistance and that they interact more strongly with the different isolates. Such genotypes can be used to differentiate isolates into physiological races.

Hsieh et al. (2005) used 15 common bean genotypes and two C. flaccumfaciens pv. flaccumfaciens isolates and did not detect differences among the genotypes and isolates. In the present study, which utilized the stability estimates described by Lin and Binns (1988) (Table 6), a genotype-isolate interaction was observed. Thus, the use of a few common bean genotypes and C. flaccumfaciens pv. flaccumfaciens isolates does not have sufficient precision to adequately represent both host and pathogen variability.

The BRS Esteio, Ouro Branco, BRS Requinte, Uirapuru, BRS Esplendor, and Vermelho genotypes were susceptible when inoculated with the more aggressive isolates. These genotypes were considered resistant when inoculated with the less aggressive isolates, which was expected. However, the Michelite, IPA 7419, TU, PI 207 262, AND 277, Pérola, IPA 6, Cornell 49242, BRS Campeiro, BAT 477, IPA 1, and Frijólica 0-3-1 genotypes showed greater resistance to the more aggressive isolates than to the less aggressive isolates. This indicates the existence of interactions between those genotypes and C. flaccumfaciens pv. flaccumfaciens isolates. For those genotypes, the less aggressive isolates most likely carry virulence genes that the hosts' resistance genes cannot recognize. It is also possible to observe a very large discrepancy in the classification obtained by some genotypes when inoculated with more aggressive " $\mathrm{P}(+)$ " and less aggressive " $\mathrm{P}(-)$ " isolates using the method described by Lin and Binns (1988) (Table 6). For example, BRS Esplendor was placed in the 21st position when inoculated with more aggressive " $\mathrm{P}(+)$ " isolates and third when inoculated with less aggressive " $\mathrm{P}(-)$ " isolates. Michelite placed second when inoculated with " $\mathrm{P}(+)$ " isolates and $22 \mathrm{nd}$ with " $\mathrm{P}(-)$ " isolates. These results provide compelling evidence that strong and specific interactions exist within this pathosystem, which contains important pathogenic physiological specialization.

Using the same method, the most aggressive isolates were concluded to be BRM 14939, BRM 14942, BRM 27254, BRM 14935, and BRM 14933. However, these isolates were less virulent against the genotypes IPA 9, Michelite, AND 277, PI 207 262, TU, IPA

Genetics and Molecular Research 15 (4): gmr15048712 
7419, Cornell 49242, Pérola, IPA 6, BRS Campeiro, BAT 477, IPA 1, and Frijólica 0-3-1. The less aggressive isolates BRM 14919, BRM 14941, and BRM 14946 were virulent against the genotypes TO, Ouro Branco, BRS Requinte, Uirapuru, BRS Esplendor, Vermelho, IAC Carioca Pyatã, BRS Cometa, BRS Notável, BRS Estilo, A211, Coquinho, IAC Carioca Akytã, and BRS Esteio. These results follow the principles of the gene-for-gene theory proposed by Flor (1971). For the later genotypes, the less aggressive isolates most likely carry virulence genes that the hosts' resistance genes cannot recognize.

Based on these results, it can be concluded that a differential interaction exists between common bean genotypes and C. flaccumfaciens pv. Alaccumfaciens isolates. For the first time, the existence of physiological specialization in this pathosystem has been demonstrated. The genotypes Coquinho, BRS Cometa, CNFP 10104, BRS Requinte, and A211 exhibited horizontal resistance and the genotypes IPA 9, Ouro Branco, Michelite, BRS Requinte, and TU genotypes exhibited specific resistance to the major isolates of the pathogen that causes bacterial wilt. The BRM 14939, BRM 14942, BRM 27254, BRM 14935, and BRM 14933 isolates exhibited the greatest aggressiveness. The BRM 14919 and BRM 14933 isolates were the most virulent to the most common bean genotypes. Based on these results, it is possible to propose the use of the IAC Carioca Akytã, BRS Notável, Pérola, IAC Carioca Aruã, and Coquinho genotypes in a provisional series of differentials for future validation with more isolates. These genotypes contributed the most to the genotype $\mathrm{x}$ host interaction and have greater potential for distinguishing between isolates of this pathogen.

\section{Conflicts of interest}

The authors declare no conflict of interest.

\section{ACKNOWLEDGMENTS}

We acknowledge with grateful thanks Embrapa Arroz e Feijão and Universidade Federal de Goiás (UFG) for providing financial support for this research, and CAPES, for financial support to S.C.D. Valdo.

\section{REFERENCES}

Carneiro PCS (1998). Novas metodologias de análise da adaptabilidade e estabilidade de comportamento. Doctoral thesis, Universidade Federal de Viçosa, Viçosa.

Collins MD and Jones D (1983). Reclassification of Corynebacterium flaccum faciens, Corynebacterium betae, Corynebacterium oortii and Corynebacterium poinsttiae in the genus Curtobacterium, as Curtobacterium flaccumfaciens comb. nov. J. Gen. Microbiol. 129: 3545-3548.

Cruz CD (2013). GENES - A software package for analysis in experimental statistics and quantitative genetics. Acta Sci. Agron. 35: 271-276. http://dx.doi.org/10.4025/actasciagron.v35i3.21251

Daher RF, Pereira MG, Amaral JR, Pereira AV, et al. (2003). Estabilidade da produção forrageira em clones de capim-elefante (Pennisetum purpureum Schum.). Cienc. Agrotec. 27: 788-797. http://dx.doi.org/10.1590/S1413-70542003000400007

Davide LMC and Souza EAD (2009). Pathogenic variability within race 65 of Colletotrichum lindemuthianum and its implications for common bean breeding. Crop Breed. Appl. Biotechnol. 9: 23-30. http://dx.doi.org/10.12702/19847033.v09n01a04

Ferreira DF (1999). Sistema para análise de variância para dados balanceados (SISVAR). UFLA, Lavras

Flor HH (1971). Current status of the gene-to-gene concept. Annu. Rev. Phytopathol. 9: 275-296. http://dx.doi.org/10.1146/ annurev.py.09.090171.001423

Genetics and Molecular Research 15 (4): gmr15048712 
Geraldi IO and Miranda-Filho JB (1988). Adapted models for the analysis of combining ability of varieties in partial diallel crosses. Rev. Bras. Genet. 11: 431-440.

Griffing B (1956). Concept of general and specific combining ability in relation to diallel crossing systems. Aust. J. Biol. Sci. 9: 463-493. http://dx.doi.org/10.1071/BI9560463

Hall R (1991). Compendium of bean diseases. American Phytopathological Society, St. Paul.

Hedges F (1926). Bacterial wilt of beans (Bacterium flaccumfaciens Hedges). Including comparisons with Bacterium phaseoli. Phytopathology 16: 1-22.

Hsieh TF, Huang HC, Mündel HH, Conner RL, et al. (2005). Resistance of common bean (Phaseolus vulgaris) to bacterial wilt caused by Curtobacterium flaccumfaciens pv. flaccumfaciens. J. Phytopathol. 153: 245-249. http://dx.doi. org/10.1111/j.1439-0434.2005.00963.x

Lin CS and Binns MR (1988). A superiority measure of cultivar performance for cultivar x location data. Can. J. Plant Sci. 68: 193-198. http://dx.doi.org/10.4141/cjps88-018

Maranha FGCB, Ramalho MAP and Farias FJC (2002). Estratégias de análise da reação de cultivares de algodoeiro a patógenos. Rev. Bras. Oleaginosas Fibrosas 6: 565-575.

Maringoni AC and Rosa EF (1997). Ocorrência de Curtobacterium flaccumfaciens pv. flaccumfaciens em feijoeiro no Estado de São Paulo. Summa Phytopathol. 23: 160-162.

Melo LC and Santos JBD (1999). Identification of resistant genotypes considering polygenic systems in host-pathogen interaction. Genet. Mol. Biol. 22: 601-608. http://dx.doi.org/10.1590/S1415-47571999000400022

Miklas PN, Kelly JD, Beebe SE and Blair MW (2006). Common bean breeding for resistance against biotic and abiotic stresses: From classical to MAS breeding. Euphytica 147: 105-131. http://dx.doi.org/10.1007/s10681-006-4600-5

Pereira R, Souza EA, Barcelos QL, Abreu AFB, et al. (2015). Aggressiveness of Pseudocercospora griseola strains in common bean genotypes and implications for genetic improvement. Genet. Mol. Res. 14: 5044-5053. http://dx.doi. org/10.4238/2015.May. 12.7

Saettler AW (1991). Diseases caused by bacteria. In: Compendium of bean diseases (Schwartz HF, Steadman JR, Hall R and Forster RL, eds.). APS Press, St. Paul, 46-52.

Schuster ML and Sayre RM (1967). A coryneform bacterium induces purple-colored seed and leaf hypertrophy of Phaseolus vulgaris and others leguminosae. Phytopathology 57: 1064-1066.

Scott AJ and Knott M (1974). A cluster analysis method for grouping means in the analysis of variance. Biometrics 30 : 507-512. http://dx.doi.org/10.2307/2529204

Silva LL (2010). Variabilidade patogênica de Xanthomonas axonopodis pv. phaseoli em feijoeiro-comum. Graduation 's thesis, Universidade Federal de Viçosa, Viçosa.

Theodoro GF, Herbes DH and Maringoni AC (2007). Fontes de resistência à murcha de Curtobacterium em cultivares locais de feijoeiro, coletadas em Santa Catarina. Cienc. Agrotec. 31: 333-339. http://dx.doi.org/10.1590/S1413$\underline{70542007000500009}$

Uesugi CH, Freitas MA and Menezes JR (2003). Ocorrência de Curtobacterium flaccumfaciens pv. flaccumfaciens em feijoeiro, em Goiás e no Distrito Federal. Fitopatol. Bras. 28: 324. http://dx.doi.org/10.1590/S010041582003000300019

Wendland A, Alencar NE, Melo LC, Costa JGCC, et al. (2009). Symptom pattern of common bean genotypes inoculated with different isolates of Curtobacterium flaccumfaciens pv. flaccumfaciens. Annu. Rep. Bean Improv. Coop. 52: 70-71.

Wendland A, Moda-Cirino V, Del Peloso MJ, Costa JGCD, et al. (2012). Murcha-de-curtobacterium. In: Melhoramento genético do feijoeiro-comum e prevenção de doenças (Júnior TJDP and Wendland A, eds.). EPAMIG, Viçosa, 111-124.

Wricke G (1965). Zur Berechnung der Ökovalenz bei Sommerweizen und Hafer. Z. Pflanzenzüchtung 52: 127-138.

Genetics and Molecular Research 15 (4): gmr15048712 